\title{
Improving Character-based Reading by Applying PQRST Method to the Students of English Education Study Program
}

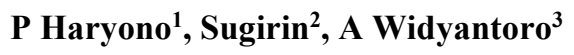 \\ ${ }^{1}$ Doctoral Student of Yogyakarta State University, Indonesia \\ ${ }^{1}$ Faculty of Teacher Training and Education Universitas Widya Dharma Klaten, Indonesia \\ ${ }^{2}$ Postgraduate Program of Yogyakarta State University, Indonesia \\ ${ }^{3}$ Faculty of Language and Arts of Yogyakarta State University, Indonesia
}

pwharyono@gmail.com

\begin{abstract}
The research aims at describing whether or not PQRST method can be used to improve character-based reading of the fourth semester students of English Education Study Program. PQRST method is assumed to be appropriate used as a teaching method to improve students reading comprehension. In this classroom action reasearch, the researchers collected the data by doing observation during teaching and learnind character-based reading, giving test, interviewing students, and delivering questionaire. The data collected from precycle to cycle two were analyzed descriptively. Based on the data analysis, it showed that PQRST method was able to improve character-based reading of the fourth semester students of English Education Study Program.
\end{abstract}

Keywords: Improving; Character; Reading

\section{INTRODUCTION}

Character education can be inserted in reading class and be implemented in its learning activities. Meanwhile, reading is one of the main priorities that should be improved through character-based education because reading is an essential skill for learners of English as a second or foreign language. For most of these learners, it is the most important skill to master in order to ensure success not only in learning English but also learning in any content class, where reading in English is required. With the strengthened reading skills, learners make greater progress and development in all other areas of learning [1]. Reading is the first way the students did to gain the knowledge. In reading activities, learners practice using text to create meaning using their background knowledge. Meaning that if there is no meaning being created, there is no reading taking place [1], [2].

Most people learn to read in their native language without difficulty. Many, but not all, learn to read as children. Some children and adults need additional help. Yet others learn to read a second, third, or additional language, with or without having learned to read in their first language. Reading instruction, therefore, needs to take into account different types of learners and their needs. Research has shown that there is a great deal of transfer from learning to read in one language to learning to read in a second language [3]. The development of word-based 
skills such as decoding and spelling points to parallel in numerous comparisons of typologically different languages [4] and [5]. When text-based aspects of reading such as reading comprehension are developed in one language, they correlate with reading comprehension in the other language [6]-[8]. The above problems are the common issues which also occur in reading class of the fourth semester students of English Education Study Program. Moreover, the empirical problems faced by the learners somehow are various as they find barriers in determining words meaning in context and developing their vocabularies. The learning strategies remain monotonous as the learners still read text and count on dictionary to find the difficult words meaning. The ability to translate word by word of a passage is no warranty of abilities to comprehend the passage content as a whole [9]. When it happens, they find it hard to identify the main idea of paragraphs or text and in turn results in the lack of reading comprehension for sure. Learners do not apply various learning strategies which can help them to fulfill their needs and are appropriate to their ability. It implies that learners get less character education inserted while they are doing less activity.

Due to the problems above, the researchers offered an interesting method to be applied in reading class which is strongly assumed be able to improve reading comprehension skill and character building simultaneously which is called PQRST, Preview, Question, Read, Summarize, and Test. The use of PQRST method has shown an improvement of the readers' understanding, and their ability to recall information [10]. In other words, the readers are more interested in learning the material they have read. Besides, the use of PQRST strategy improves the effectiveness of the teaching and learning process which, then, increases the students' reading comprehension. Self-recitation or summarizing step is particularly effective if done properly, as is the questioning step [11].

The use of PQRST method can also improve learners' character. It is due not only to cognitive factors but also to affective ones of the learners [12]. Some of which are intelligence, aptitude, personality, motivation and attitude, learning style, and age of acquisition [13]. It is clearly described there is a relation between learning strategies and learning style as the result of cognitive and affective development. Reid (1995) as cited in [14], presents a comprehensive and categorical framework of learning styles divided into three major categories: cognitive learning styles, sensory learning styles, and personality learning styles. Therefore, the researchers are highly intended to conduct classroom action research (CAR) in order to improve the teaching and learning character-based reading by applying PQRST method to the fourth semester students of English Education Study Program.

\section{METHOD}

The research was a classroom action research (CAR) since the researchers wanted to improve character based reading ability. The subjects of the research were both lecturers of reading and the students of the fourth semester of English Education Study Program. The researchers used test, observation, interview and questionnaire to get data. The tests were conducted at the end of cycle 1 and cycle 2, in form of multiple choice with four options and 30 items. The same questions were provided for both cycle 1 and cycle 2 test but with different order. Observation was administered to know the students' activities and participation, while interview and questionnaire were used to find out the students' response in applying PQRST which was simultaneously developing character in reading class. The collected data were analyzed qualitatively and quantitatively. 


\section{FINDINGS AND DISCUSSION}

\subsection{Findings}

In the beginning of the research, the pre-scores were taken from the pre-test done by 20 fourth semester students. The result of the pre-test can be seen in table 1 .

Table 1. Pre-Cycle Students' Score Category

\begin{tabular}{ccc}
\hline Category & Total & Percentage \\
\hline Excellent & 0 & - \\
Good & 3 & 15 \\
Average & 17 & 85 \\
Poor & 0 & - \\
\hline
\end{tabular}

In planning steps, the researchers discussed the teaching preparation, designed teaching and learning activities, and constructed syllabus, lesson plan, and test implementing PQRST method to teach character-based reading. These activities were conducted in one meeting and resulted 1) teaching document preparation which could encourage students to be able to do previewing, questioning, reading, summarizing, and testing by themselves during they read a text; 2) teaching activities which engaged students to improve the character education (respect, bravery, confidence, curiosity) during they were reading as they were involved in team work, presentation, discussion, and question and answer activities; 3) the test; and 4) the observation sheet to collect the qualitative data.

In acting step, the researchers did teaching and learning reading by applying PQRST method. At the same time the researchers did observation. While in the reflecting step, the researchers discussed the result of cycle 1 , table 2 , and finally decided to come to cycle 2 . The students scores gained from cycle 1 and 2 can be seen in table 2, while the average is shown in table 3 .

Table 2. Cycle 1 and 2 Students' Score Category

\begin{tabular}{ccccc}
\hline \multirow{2}{*}{ Category } & \multicolumn{2}{c}{ Total } & \multicolumn{2}{c}{ Percentage } \\
\cline { 2 - 5 } & Cycle 1 & Cycle 2 & Cycle 1 & Cycle 2 \\
\hline Excellent & 2 & 15 & 10 & 75 \\
Good & 9 & 5 & 45 & 25 \\
Average & 9 & 0 & 45 & - \\
Poor & 0 & 0 & - & - \\
\hline
\end{tabular}

The students' character was assessed using observation form during the implementation of PQRST method. The observation form covered three main aspects which assessed both the ability of learning reading (knowledge) and character education (attitude and action). The result of the assessments showed the improvement of developing students character in learning reading. Students' attitude aspects were integrated to the PQRST activities consisting of respect, bravery, confidence, and curiosity. Meanwhile, the action aspects consisted of teamwork and communication action. The result of students character assessment is shown in table 3 . 
Table 3. The Class Character Scores Classification

\begin{tabular}{cccccc}
\hline & \multicolumn{2}{c}{ Cycle 1 } & \multicolumn{3}{c}{ Cycle 2 } \\
\hline Mean & Category & Classification & Mean & Category & Classification \\
\hline 68 & $\mathrm{C}$ & Average & 86 & B & Good \\
\hline
\end{tabular}

\subsection{Discussion}

The research findings proved that the implementation of PQRST method can improve students' ability in comprehending text and students' character. The improvements were judged by comparing the mean scores of pre-cycle, cycle 1 , and cycle 2 . It is in line with the theory that PQRST method is one of strategies that can lead the students reading comprehension [10]. Each step of PQRST method improves the teaching and learning process which is also aimed at improving the students' reading comprehension.

Based on observation, it can be drawn that the students' participation gradually increased in every cycle after applying PQRST method. It indicated they were able to do the PQRST procedures and enjoyed on following the activities which is exactly in line with theory proposed by Johnson \& Anderson that the stages in the PQRST strategy underline the constructivist nature of learning noting that reading is an active, often necessarily selective, effortful and iterative process. Students were able to develop their bravery and curiosity on asking some questions, engaging on discussion board, and stating opinion rather than before they applied PQRST

\section{CONCLUSION}

Based on two cycles done in this research, it can be concluded that PQRST method can be used to improve students character-based reading with various text type and levels of difficulties. The improvements were shown by the enhancement of students' mean scores in every cycle, 62,71 , and 86 for cycle 1,2 , and 3 respectively.

\section{REFERENCES}

[1] N. Anderson, Practical English Language Teaching: Reading. New York: McGrawHill, 2008.

[2] Johnson and P. Andrew, Teaching Reading and Writing: A Guide Book for Tutoring and Remediating Students. New York: Rowman and Littlefield Education, 2008.

[3] D. B. Rao, Educational Practices: Research and Recommendations. New Delhi: Discovery Publishing House, 2004.

[4] N. Lesaux, K. Koda, L. Siegel, and T. Shanahan, "Developing Literacy in Second Language Learners: Report of the National Literacy Panel on Language Minority Children and Youth," in Developing Literacy in Literacy, D. August and T. Shanahan, Eds. New Jersey: Lawrence Erlbaum, 2006, pp. 75-122.

[5] L. Wade-woolley and L. S. Siegel, "The Spelling Performance of ESL and Native Speakers of English as a Function of Reading Skill," Read. WritingAn Interdiscip. J., vol. 9, no. 5-6, pp. 387-388, 1997.

[6] L. T. Verhoeven, "Transfer in Bilingual Development: The Linguistic Interdependence Hypothesis Revisited," Lang. Learn. A J. Res. Lang. Stud., vol. 44, no. 3, pp. 381-415, 
1994.

[7] C. Dressler and M. Kamil, "First and Second Language Literacy," in Developing Literacy in Second Language Learners: Report of the National Literacy Panel on Language-Minority Children and Youth, D. August and T. Shanahan, Eds. New York: Lawrence Erlbaum, 2006.

[8] L. Reese, L. Beach, R. G. Gallimore, L. Angeles, and C. Goldenberg, "Longitudinal Analysis of the Antecedents of Emergent Spanish Literacy and Middle-School English Reading Achievement of Spanish-Speaking Students," Am. Educ. Res. J., vol. 37, no. 3, pp. 633-662, 2000.

[9] Sulistyo and G. H., Reading for Meaning. Malang: Pustaka Kaiswaran, 2011.

[10] T. F. Staton, How to Study. Nashville: Illinois University Press, 1982.

[11] N. Malia, A. Yasin, and Kusni, "Using PQRST Strategy to Improve Students' Reading Comprehension of Hortatory Exposition Texts at Grade XI IPS of MA Diniyah Putri, Pekanbaru," J. English Lang. Teach., vol. 3, no. 1, pp. 79-85, 2015.

[12] H. D. Brown, Principles of Language Learning and Teaching. New York: Pearson Education, 2007.

[13] P. M. Lightbown and N. Spada, How Languages are Learned. Oxford: Oxford University Press, 1993.

[14] N. Sadeghi, Z. M. Kasim, B. H. Tan, and F. S. Abdullah, "Learning Styles, Personality Types and Reading Comprehension Performance," English Lang. Teach., vol. 5, no. 4, pp. 116-123, 2012. 